Janis Karklins, Dr. iur., Associate Professor

University of Latvia, Latvia

\title{
THIRD-PARTY'S FAULT AS AN EXCLUSION FROM STRICT LIABILITY
}

\begin{abstract}
Summary
This article is dedicated to analysis of general regulation of strict liability model in context of circumstances excluding third party's liability. Besides the most common exceptions for imposition of strict liability, i.e. intent or gross negligence of the very victim and force majeure, the article also discusses another exception that can be found more often in legislation of different countries - a culpable conduct of third party. The exception noted in the article is analysed in the context of possession of an object of increased risk, seeking an answer to a question whether and in what cases a possessor of a source of increased risk is not liable for damage caused, where the source of increased risk is involved.
\end{abstract}

Keywords: civil liability, strict liability, fault, exclusions from strict liability, source of increased risk, abnormally dangerous activities, fortuitous event (cas fortuit), causation, foreseeability, negligence, third-party's fault

\section{Introduction}

Precise determination of civil liability, i.e., which person and to what extent is liable for infringement of rights, is one of the most important questions of the civil law. It is especially important in tort law. Specific nature of tort law differs (unlike the contractual law) that victim usually cannot foresee occurrence of person's infringement (unlawful conducts). Therefore, tort law is regulated stricter, it has imperative regulation, because basically it protects property and non-pecuniary benefits of a person. Unlike contractual relationships, in case of tort, the victim is a person that do not cooperate with the tortfeasor and hence they cannot protect themselves in advance from the potential infringement. Regulation of tort law serves not only to identify the person liable, but it is also preventive ${ }^{1}$ - precluding other persons from a conduct that is not accepted as correct by general public. Therefore, precise regulation and correct understanding of legal provisions regarding situations when strict liability is or is not imposed on a person is an essential element for strengthening the principle of legal certainty.

One of the areas allowing exceptions from general concept of civil liability, is the area of strict liability, which facilitates upholding of the tortfeasor's liability. When evaluating the strict liability model, it is important to accurately define

Torgāns K., Kārkliňš J., Bitāns A. Līgumu un deliktu problēmas Eiropas Savienībā un Latvijā. Prof. K. Torgāna zinātniskā redakcijā [The Contract and Tort Problems in European Union and Latvia. Torgāns K. (scientific ed.) ]. Tiesu namu aǵentūra. Rìga, 2017, p. 263. 
the cases excluding imposition of strict liability. This article is aimed at analysing whether culpable conduct of third-party is also one of exclusions of strict liability.

\section{The most common exceptions of strict liability in context of the concept of fault}

Usually, when someone asks for a difference between a fault-based model and a strict liability model, the answer mainly is that the strict liability model does not evaluate fault, in other words, a person is liable even if there is no negligence in his or her conduct.

Nevertheless, the question is - whether such a simple answer is correct, namely - does the fault play no role indeed in the strict liability model? And if it does, which person's fault is the one playing that role - the fault of a tortfeasor, a victim or a third party? Research and work completed during the recent years have led me to a conclusion that the strict liability and a concept of fault are not distinctly separate.

If we look at the regulation of strict liability in Latvia, the general legal framework applies the strict liability to the damage caused by a source of increased risk. Article 2347 of Latvian CL states:

A person whose activity is associated with increased risk for other persons (transport, enterprise, construction, dangerous substances, etc.) shall compensate for damage caused by the source of increased risk, unless he or she proves that the damage has occurred due to force majeure, or through the victim's own intentional act or gross negligence. If a source of increased risk has arisen from the possession of an owner, holder or user, without their fault, but as a result of unlawful actions of another person, such other person shall be liable for the damage incurred. If the possessor (owner, holder, user) has also acted without justification, both the person who used the source of increased risk and its possessor may be held liable for the damage incurred, having regard to extent of fault of each person.

The above article indicates that fault has some role in indicating whether the person is liable in accordance with the strict liability. Thus, several bullet points can be highlighted in context of the said article:

- Firstly, force majeure event. To establish force majeure, the event needs to meet some criteria. There will be force majeure if the event was not foreseeable and irresistible. Evaluating if the event was force majeure from the perspective of the person violating the rights, one must evaluate an "ability to foresee". As we know, the "ability to foresee" is an element of general clause of a reasonable person, which is highly connected to the concept of fault. There is a possibility that, due to fault of the very tortfeasor, the event has not been prevented, even though it was possible! In that case, there are no grounds to conclude that there was force majeure. To put it otherwise, when evaluating a force majeure event, one must also evaluate the elements of fault. 
- Secondly, intent and gross negligence of the victim. No doubt, intent and negligence are elements or degrees of fault. Therefore, when assessing whether the tortfeasor is subject to the strict liability, one must evaluate conduct of the victim, which also is highly connected to the concept of reasonable person and fault.

- Thirdly, unlawful conduct of third party. According to this, there is no strict liability, if the source of increased risk has arisen out of possession of an owner, holder or user without his or her fault. Thus, also in this case, when evaluating a possibility to impose the strict liability, one must consider the fault of the owner of source of increased risk. In other words, has the unlawful conduct of third party occurred due to negligence of the very possessor?

Unlike the fault-based model, strict liability does not set in only in cases precisely defined in the law. These particular exceptions stated in the law have always been listed in detail and they never include an excuse for not imposing a liability, such as lack of fault (lack of negligence). At the same time, it must be admitted that there is no common catalogue of exceptions excluding strict liability ${ }^{2}$. In each area of private law, the legislator can provide different exceptions.

Exceptions the civil liability in case of the strict liability model, depend on the field of legal relations. Considering diverse regulations in Latvia containing the strict liability model, in addition to force majeure one can find the following exclusive circumstances (they are not exhaustive):

a. in case of a source of increased risk:

i. gross negligence or intent of the very victim;

ii. loss of possession over the object due to unlawful conduct of third party;

b. in environmental law:

i. armed conflict, war; civil war; rebellion ${ }^{3}$;

c. in field of maritime shipment:

i. conduct of third party if it intended to cause loss;

ii. due to an institution, which is responsible for maintenance of technical navigation means ${ }^{4}$.

d. in field of consumer rights:

i. person has not put a product in circulation;

ii. defect of product, leading to a loss, has set in after putting the product in circulation;

2 Kārklinš̌ J. Stingro atbildību izslēdzoši apstākḷi [Exceptions of strict liability]. LU 74. konferences rakstu krājums. Ārvalstu investīcijas: kad tiesības mijiedarbojas. LU akadēmiskais apgāds. Rīga, 2016, p. 123.

3 Vides aizsardzības likums [Environmental Protection Law]. Latvijas Vēstnesis, 183, 15.11.2006.

4 Jūras kodekss [Maritime Code]. Latvijas Vēstnesis, 91 (2856), 18.06.2003. 
iii. the product was not manufactured to be put in circulation or other kind of dissemination to gain profit; and it was not manufactured or disseminated within the framework of economic activities;

iv. level of science and technical development at a time when the product was put in circulation was not that high to discover a defect or shortcoming;

v. defect of product was a result of manufacturer complying with requirements set by the state or local government ${ }^{5}$.

As it can be seen from these exclusions of liability, a part of them can be attributed to a fortuitous event, i. e., an event triggered by unforeseeable and irresistible events, including those resulting from conduct of third parties, for example "armed conflict" in field of environmental law or "conduct of third party" in field of maritime shipment. Nonetheless, fortuity as an exclusion of strict liability is not a common exception, or, to rephrase it, the legal system admits regulation that applies strict liability regardless of whether a damage has been caused by fortuitous event. In certain cases, exclusion of strict liability is unlawful conduct of third party that is believed to be a fortuitous event. Thus, the legal system may have a regulation, according to which a fortuitous event is deemed to be an exclusion of strict liability.

\section{Role of third party's culpable (unlawful) conduct in strict liability model}

When looking at provisions of Article 2347 of CL, one can conclude that it does not contain an explicit indication that unlawful conduct of third party is always an exclusion of strict liability. According to provisions of Article 2347 of CL, unlawful conduct of third party is an exclusion of strict liability in case where third party has unlawfully taken away possession over the source of increased risk.

However, there is one important question to be discussed in this article, namely: is an exclusion of the strict liability solely a detected culpable conduct of third party that is related to unlawful impact of third party on an object under its possession?

No doubt, that in case of unlawful loss of the source of increased risk under his possession, the former possessor would not be liable for damage caused by the source of increased risk. But the question remains - is the strict liability excluded also in other cases when a damage is done by the source of increased risk, but its direct cause is pure conduct of third party?

Generally, unlawful conduct of third party is not force majeure but rather a fortuitous event ( cas fortuit, in Latin) which, in general tort law (and in many cases also in contract law) is an exclusion of liability. However, in case of the strict liability, a fortuitous event is not considered as a general exclusion of liability in Latvia. Otherwise, the strict liability model would be very similar to the fault model.

Likuma "Par atbildību par preces un pakalpojuma trūkumiem" 8. panta otrā daḷa [Law "On Liability for Defective Goods and Deficient Services”]. Latvijas Vèstnesis, 250/251 (2161/2162), 05.07.2000. 
Notwithstanding that, a reasonable question must be posed and answered: When a damage is done by the source of increased risk, but the cause of damage is the conduct of third party, is it correct to say that such unlawful conduct of third party is an exclusion of the strict liability or is not?

When describing the concept of the strict liability, the well-known Latvian lawyer Jülijs Gilmanis, back in 1979, proposed a thesis that, if a person were to push another person onto the street in front of a driving car consequently resulting in a fatal outcome, a driver of the car would be liable for the resulting death ${ }^{6}$.

No doubt, in this case we cannot establish any exclusion of the strict liability included expresis verbis under Article 2347 of CL - neither force majeure, intent of victim himself nor gross negligence, nor unlawful conduct of third party in relation to deprivation of possession can be established. However, is the idea of strict liability so strict indeed, that the subject who cannot avoid such situation even preventively is liable in case of obvious unlawful conduct of third party?

In order to answer this question, we must remember why the idea of the strict liability was introduced in legal systems. Namely, as the technologies evolved, humanity invented devices that were dangerous due to their properties, and it was impossible to lessen this hazard even by paying utmost attention and care in operating these devices ${ }^{7}$. If the fault-based model would be applied in such cases, the liability could not be claimed, because tort would result from the properties of very device instead of negligence of a person, hence - incidentally. Therefore, the strict liability concept was introduced in law. When evaluating this idea of the strict liability in context of cars, it can be concluded that the idea was introduced, because cars move with greater speed than other means of transport, they can accidentally break, even explode etc. It means that the source of increased risk has certain risk that can occur. Beyond doubt, the strict liability in transport area was not introduced because of situations where third parties intentionally pushed people in front of cars on a regular basis to cause their death.

Therefore, it is not correct to say that possessor of the source of increased risk is always liable for every tort where the source of increased risk is involved.

Answer to previously posed question - is the car driver liable for death of a person who was unexpectedly pushed in front of the car - is negative. In other words, third-party's fault - the intent and resulting step to push the person in front of a moving car - excludes the liability of the driver.

Gilmanis J., Grebņickis P., Krauze R., Narkevičs G., Naumovs V., Rozenfelds J., Strautmanis J., Šulcs V., Torgāns K. Latvijas PSR Civilkodeksa komentāri [Commentaries of the Civil Code of the Latvian SSR]; Vëbers J. (ed.), Rìga. Liesma, 1979. p. 602.

7 Kubica M.L. Origins of Strict Liability for Abnormally Dangerous Activities in the United States, Rylands v. Fletschers a General Clause of Strict Liability in UK. In: World Academy of Science, Engineering, and Technology. International Journal of Social Behavioural, Educational Economic, Business and Industrial Engineering, Vol. 10, No. 3, 2016, p. 870. Available at: http://waset.org/ publications / 10004037/origins-of-strict-liability-for-abnormally-dangerous-activities-in-theunited-states-rylands-v.-fletschers-and-a-general-clause-of-strict-liability-in-the-uk [last viewed October: 25, 2019]. 
In this case, it is not possible to establish a legal causality between possessing a source of increased risk and resulting tort, because the cause of death is rather the unlawful conduct of third party than the risk posed by the source of increased risk, and this absolutely disrupts the causality link between normal use of the car and consequences.

When trying to evaluate, whether an external circumstance excludes the strict liability, one must conclude that this cause is adequate in relation to use of the source of increased risk. Therefore, a driver whose eye was accidentally affected by a fly leading to a traffic accident will be subject to the strict liability, because this situation qualifies for a category of usual risk related to use of such source of increased risk. Quite on the opposite, the usual risk of using the car does not involve an unexpected pushing of a person in front of the car by another person.

Conduct of third party as an exclusion of strict liability is included also in Principles of European Tort Law ${ }^{8}$, Art.7:102, stating that "Defences against strict liability" envisage that strict liability can be excluded or reduced if the injury was caused by an unforeseeable and irresistible:

a) force of nature (force majeure), or

b) conduct of third party.

When considering the conduct of third party as an exclusion of strict liability model, one must bear in mind that it is not always necessary to establish unlawful conduct of third party. There can be situations where the conduct of third party has caused damage, but that particular conduct in given circumstances is not deemed to be unlawful (for example, self-defence of third party, ultimate need etc.). At the same time, such conduct of third party can be an exclusion of strict liability for the possessor of the source of increased risk.

Taking into consideration the questions analysed in present article, it is possible to make the following conclusion: Exclusions of strict liability under Article 2347 of Latvian Civil Code are not the only ones excluding application of such liability. Without the exclusions mentioned in that article, the judge must also evaluate, whether a tort has been caused by materialisation of the risk inherent in the source of increased risk.

Regulation of strict liability shows that strict liability is a complicated construct, having specific exclusions in each field. According to Dutch legal scientist Cees van Dam, strict liability is an ambiguous and controversial concept, even a kind of fiction, because elements of unlawful conduct and fault (even indirectly) in any case play an important role in application of this concept and it is not possible to differentiate between clear strict liability and fault-based liability?

8 European Group on Tort Law, Principles of European Tort Law, Text and Commentary. Springer, Vienna/New York, 2005.

9 Cees van Dam. European Tort law. Second Edition. Oxford: Oxford University Press, 2013, p. 479. 


\section{Conclusions}

1. It is incorrect to state that possessor of the source of increased risk is always liable for every tort where the source of increased risk is involved.

2. When trying to evaluate whether an external circumstance excludes the strict liability, one must conclude that the cause is adequate in relation to use of the source of increased risk.

3. In most cases, strict liability is excluded in cases when a damage is done by the source of increased risk, but its direct cause is purely the conduct of third party.

4. When considering the conduct of third party as an exclusion of strict liability model, one must bear in mind that it is not always necessary to establish an unlawful conduct of third party. There can be situations, where the conduct of third party has caused damage, but that particular conduct in given circumstances is not deemed to be unlawful.

5. Exclusions of strict liability under Article 2347 of Latvian Civil Code are not the only ones excluding application of strict liability.

\section{BIBLIOGRAPHY}

\section{Literature}

1. Torgāns K., Kārkliņš J., Bitāns A. Līgumu un deliktu problēmas Eiropas Savienībā un Latvijā. Prof. K. Torgāna zinātniskā redakcijā [The Contract and Tort Problems in European Union and Latvia. Torgāns K. (scientific ed.)]. Rìga: Tiesu namu aǵentūra, 2017, p. 263.

2. Gilmanis J., Grebņickis P., Krauze R., Narkevičs G., Naumovs V., Rozenfelds J., Strautmanis J., Šulcs V., Torgāns K. Latvijas PSR Civilkodeksa komentāri [Commentaries of the Civil Code of the Latvian SSR]. Vēbers J. (ed.), Rīga: Liesma, 1979, p. 602.

3. Kubica M. L. Origins of Strict Liability for Abnormally Dangerous Activities in the United States, Rylands v. Fletschers a General Clause of Strict Liability in UK, World Academy of Science, Engineering, and Technology. International Journal of Social Behavioural, Educational Economic, Business and Industrial Engineering, Vol. 10, No. 3, 2016, p. 870. Available at: http://waset.org/publications/10004037/origins-of-strict-liability-for-abnormallydangerous-activities-in-the-united-states-rylands-v.-fletschers-and-a-general-clause-of-strictliability-in-the-uk [last viewed October 25, 2019].

4. European Group on Tort Law, Principles of European Tort Law, Text and Commentary. Springer, Vienna/New York, 2005.

5. Cees van Dam. European Tort Law. Second Edition. Oxford: Oxford University Press, 2013, p. 479.

6. Kārkliņš J. Stingro atbildību izslēdzoši apstākḷi [Exceptions of strict liability]. Papers of the $74^{\text {th }}$ Scientific Conference of the University of Latvia. Foreign Investment: When Law Interacts. University of Latvia Press, Riga, 2016, p. 123.

\section{Legislative acts}

1. Vides aizsardzības likums [Environmental Protection Law]. Latvijas Vēstnesis, 183, 15.11.2006.

2. Jūras kodekss [Maritime Code]. Latvijas Vēstnesis, 91 (2856), 18.06.2003.

3. Likums "Par atbildību par preces un pakalpojuma trūkumiem" [Law "On Liability for Defective Goods and Deficient Services”]. Latvijas Vēstnesis, 250/251 (2161/2162), 05.07.2000. 